\title{
Investigation of Uranium Polymorphs
}
L. Sweet
C. Henager Jr.
S. Hu
T. Johnson
D. Meier
S. Peper
J. Schwantes

August 2011

Pacific Northwest

NATIONAL LABORATORY

Proudly Operated by Battelle Since 1965 


\title{
DISCLAIMER
}

This report was prepared as an account of work sponsored by an agency of the United States Government. Neither the United States Government nor any agency thereof, nor Battelle Memorial Institute, nor any of their employees, makes any warranty, express or implied, or assumes any legal liability or responsibility for the accuracy, completeness, or usefulness of any information, apparatus, product, or process disclosed, or represents that its use would not infringe privately owned rights. Reference herein to any specific commercial product, process, or service by trade name, trademark, manufacturer, or otherwise does not necessarily constitute or imply its endorsement, recommendation, or favoring by the United States Government or any agency thereof, or Battelle Memorial Institute. The views and opinions of authors expressed herein do not necessarily state or reflect those of the United States Government or any agency thereof.

\author{
PACIFIC NORTHWEST NATIONAL LABORATORY \\ operated by \\ BATTELLE \\ for the \\ UNITED STATES DEPARTMENT OF ENERGY \\ under Contract DE-AC05-76RL01830
}

Printed in the United States of America
Available to DOE and DOE contractors from the Office of Scientific and Technical Information,
P.O. Box 62, Oak Ridge, TN 37831-0062;
ph: (865) 576-8401
fax: $(865)$ 576-5728
email: reports@adonis.osti.gov

\begin{abstract}
Available to the public from the National Technical Information Service, U.S. Department of Commerce, 5285 Port Royal Rd., Springfield, VA 22161 ph: (800) 553-6847 fax: $(703) 605-6900$ email: orders@ntis.fedworld.gov online ordering: http://www.ntis.gov/ordering.htm
\end{abstract}

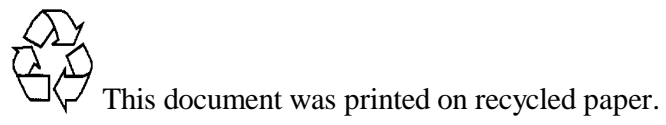




\title{
Investigation of Uranium Polymorphs
}

\author{
L. Sweet \\ C. Henager Jr. \\ S. $\mathrm{Hu}$ \\ T. Johnson \\ D. Meier \\ S. Peper \\ J. Schwantes
}

August 2011

Prepared for

the U.S. Department of Energy

under Contract DE-AC05-76RL01830

Pacific Northwest National Laboratory

Richland, Washington 99352 



\section{Executive Summary}

The $\mathrm{UO}_{3}$-water system is complex and has not been fully characterized, even though these species are common throughout the nuclear fuel cycle. As an example, most production processes for $\mathrm{UO}_{3}$ result in a mixture of up to six or more different polymorphic phases, and small differences in these conditions will affect phase genesis that ultimately result in measureable changes to the end product. As a result, this polymorphic feature of the $\mathrm{UO}_{3}$-water system may be useful as a means for determining process history. This research effort attempts to better characterize the $\mathrm{UO}_{3}$-water system with a variety of optical techniques for the purpose of developing some predictive capability for estimating process history in polymorphic phases of unknown origin. Three commercially relevant production methods for the production of $\mathrm{UO}_{3}$ were explored. Previously unreported low temperature routes to $\beta$ - and $\gamma-\mathrm{UO}_{3}$ were discovered. Raman and fluorescence spectroscopic libraries were established for pure and mixed polymorphic forms of $\mathrm{UO}_{3}$ in addition to the common hydrolysis products of $\mathrm{UO}_{3}$. An advantage of the sensitivity of optical fluorescence microscopy over x-ray diffraction has been demonstrated. Preliminary aging studies of the $\alpha$ and $\gamma$ forms of $\mathrm{UO}_{3}$ have been conducted. In addition, development of a 3-D phase field model used to predict phase genesis of the system was initiated. Thermodynamic and structural constants that will feed the model have been gathered from the literature for most of the $\mathrm{UO}_{3}$ polymorphic phases. 



\section{Contents}

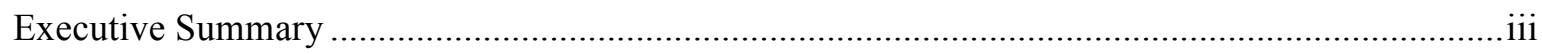

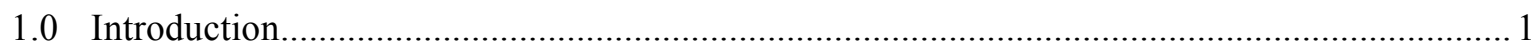

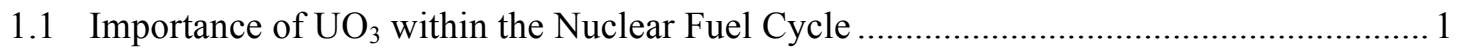

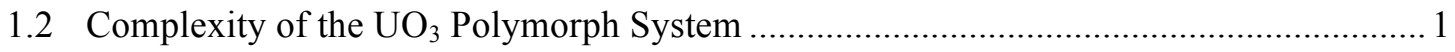

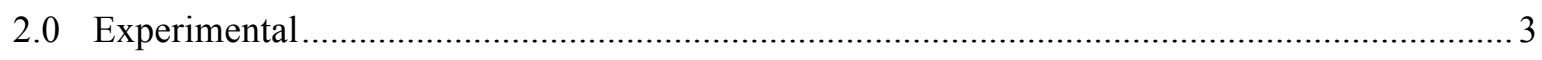

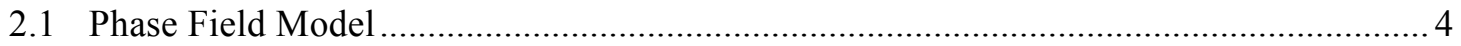

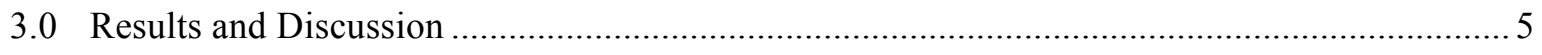

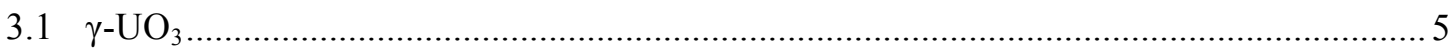

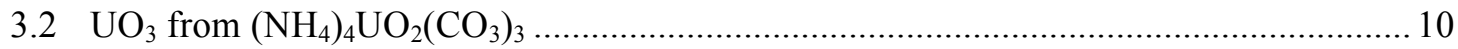

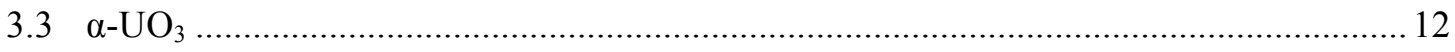

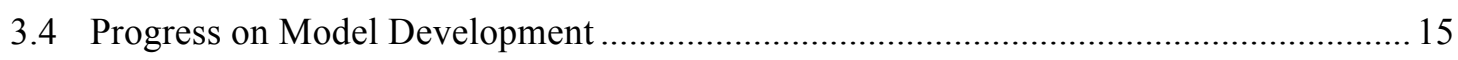

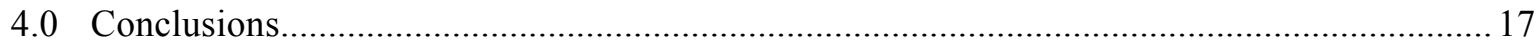

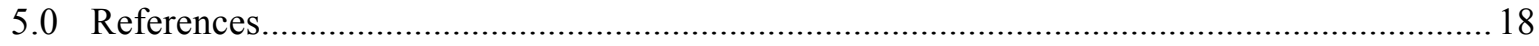





\subsection{Introduction}

This project sought to enhance the current understanding of the process-specific evolution of $\mathrm{UO}_{3}$ polymorph species through the combined application of traditional (x-ray diffraction) and more novel optical (Raman and fluorescence) spectroscopic analyses. By focusing on production methods of $\mathrm{UO}_{3}$ relevant to uranium fuel production we were able to identify signatures that will aid in the determination of the genesis and age of a $\mathrm{UO}_{3}$ sample. In addition, the development of a simplified 3-D Phase Field model for the $\mathrm{UO}_{3}$ polymorph system was started. The goal for the phase field model was to function as a tool for predicting phase genesis under a variety of real and hypothesized conditions.

\subsection{Importance of $\mathrm{UO}_{3}$ within the Nuclear Fuel Cycle}

Polymorphs of $\mathrm{UO}_{3}$ are important to mining, milling, refinement and conversion processes that precede isotope enrichment within the nuclear fuel cycle. Uranium enriched from either ore concentrates or recycled spent nuclear fuel undergoes a refinement process that produces the intermediate species $\mathrm{UO}_{3}$ from the denitration of uranyl nitrate hexahydrate (UNH) after purification (typically) by solvent extraction. The trioxide uranium species is then reduced to $\mathrm{UO}_{2}$ and subsequently converted to $\mathrm{UF}_{4}$, and ultimately $\mathrm{UF}_{6}$, by fluorination prior to enrichment. $\mathrm{The}^{\mathrm{UO}_{3}}$ species is also an intermediate product of uranium mining from carbonate rich gangue.

\subsection{Complexity of the $\mathrm{UO}_{3}$ Polymorph System}

Previous work has demonstrated that different structural forms of $\mathrm{UO}_{3}$ can be made using different starting materials and reaction conditions (as summarized in table 1). The polymorphic forms of $\mathrm{UO}_{3}$ resulting from reaction conditions that involve high pressures of $\mathrm{O}_{2}(\sim 40 \mathrm{~atm})$ have been left out of table 1. The structures of the various polymorphs of $\mathrm{UO}_{3}$ have been well characterized in many studies using $\mathrm{x}$-ray and neutron diffraction (see table 1). In addition to six different polymorphic forms of $\mathrm{UO}_{3}$ that can be made at atmospheric pressure, there are several different hydrolysis products of $\mathrm{UO}_{3}$ that form depending on the conditions $\mathrm{UO}_{3}$ is subjected to. Hydrolysis products of $\mathrm{UO}_{3}$ form at room temperature in humid air. ${ }^{1}$

$\mathrm{X}$-ray Diffraction (XRD) patterns have been established for the $\mathrm{UO}_{3}$ system, however, this technique is incapable of fully capturing the complexity of this system, which often represents mixtures of six or more polymorphic, amorphous and hydrolyzed species. In these instances where the limitations of XRD to detect amorphous species and minor components to less than $\sim 5 \%$ abundance are most evident, the application of complimentary optical techniques may be advantageous. Optical spectroscopic techniques are more accurate in quantifying ratios of mixed products and can have a much lower detection limit for minor constituents. Some of these techniques are also capable of characterizing amorphous species. However, the application of optical spectroscopy to solid phases is relatively new and presents challenges of its own. Comparison databases for these types of characterizations are largely absent. Some of these techniques are also sensitive to surface roughness and the particle size of the individual samples, making comparisons between different samples of the same materials difficult. Nonetheless, we aim to exploit the advantages of optical characterization of solid phase materials. 
A start was made on the development of a comprehensive phase field model intended to describe the complex polymorphic system of $\mathrm{UO}_{3}$. The approach uses methods developed by the Pacific Northwest National Laboratory (PNNL) to include chemical, interfacial, and elastic free energies in a 3-D coupled model that also includes time-dependent processes, such as diffusion, to predict the phase stabilities of various solid phases during phase transformations. This method can be used to predict the observed phase transitions in the $\mathrm{UO}_{3}$ system as a function of temperature, oxygen pressure, and time. $\mathrm{The}^{\mathrm{UO}_{3}}$ system requires additional developments to include oxygen partial pressures in the gas phase and oxygen vacancy terms in the chemical free energy descriptions. Since the various $\mathrm{UO}_{3}$ phases differ only in crystal structure with the same U-O ratio, the model needs to be able to differentiate between these crystal structure energies, and this requires a more detailed approach. To implement the details of oxygen stoichiometry required to capture the correct phase equilibria in $\mathrm{UO}_{3}$ a thermochemical model of the solid needs to include $\mathrm{U}, \mathrm{O}$, and $\mathrm{O}$-vacancy terms in three sublattices. We started the process of developing a diffusion-based phase field model of phase equilibria in $\mathrm{UO}_{3}$ powders beginning with amorphous powders precipitated from solution but containing $\alpha-, \beta-$, and $\gamma$-phase nuclei that compete for dominance during heating in air. The model will account for oxygen concentration gradients in powders and elastic and interface energy terms during phase transformations. Temperature effects will be accounted for in oxygen mobilities and chemical free energy terms.

Table 1. Preparation methods for the different phases of $\mathrm{UO}_{3}$. All reactions are carried out in air unless otherwise stated. Excluded are the routes to the different phases that require pressure of $\mathrm{O}_{2}$ greater than 1 atmosphere.

\begin{tabular}{|l|l|l|l|}
\hline Phase & Starting material & Conditions & Reference \\
\hline $\mathrm{A}-\mathrm{UO}_{3}$ & $\begin{array}{l}\mathrm{UO}_{4} \bullet 2 \mathrm{H}_{2} \mathrm{O}, \mathrm{UO}_{2} \mathrm{C}_{2} \mathrm{O}_{4} \bullet 3 \mathrm{H}_{2} \mathrm{O}, \\
\left(\mathrm{NH}_{4}\right)_{4} \mathrm{UO}_{2}\left(\mathrm{CO}_{3}\right)_{3}\end{array}$ & $400^{\circ} \mathrm{C}$ & 2 \\
\hline$\alpha-\mathrm{UO}_{3}$ & $\mathrm{UO}_{4} \bullet 2 \mathrm{H}_{2} \mathrm{O}$, & $400-470^{\circ} \mathrm{C}$ & 3 \\
\hline$\beta-\mathrm{UO}_{3}$ & $\begin{array}{l}\mathrm{UO}_{2}\left(\mathrm{NO}_{3}\right)_{2} \bullet 6 \mathrm{H}_{2} \mathrm{O}, \\
\text { "( }\left(\mathrm{NH}_{4}\right)_{2} \mathrm{U}_{7} \mathrm{O}_{22} \text { " }\end{array}$ & $\begin{array}{l}\text { Heat rapidly to } 450- \\
500^{\circ} \mathrm{C}\end{array}$ & 4 \\
\hline$\gamma-\mathrm{UO}_{3}$ & $\mathrm{UO}_{2}\left(\mathrm{NO}_{3}\right)_{2} \bullet 6 \mathrm{H}_{2} \mathrm{O}$ & $400-600^{\circ} \mathrm{C}$ & 5,6 \\
\hline$\delta-\mathrm{UO}_{3}$ & $\beta-\mathrm{UO}_{2}(\mathrm{OH})_{2}$ & $375^{\circ} \mathrm{C}$ & 2 \\
\hline$\varepsilon-\mathrm{UO}_{3}$ & $\mathrm{U}_{3} \mathrm{O}_{8}$ & $\begin{array}{l}350^{\circ} \mathrm{C} \text { in a flow of } \mathrm{NO}_{2} \\
\text { gas }\end{array}$ & 2 \\
\hline
\end{tabular}




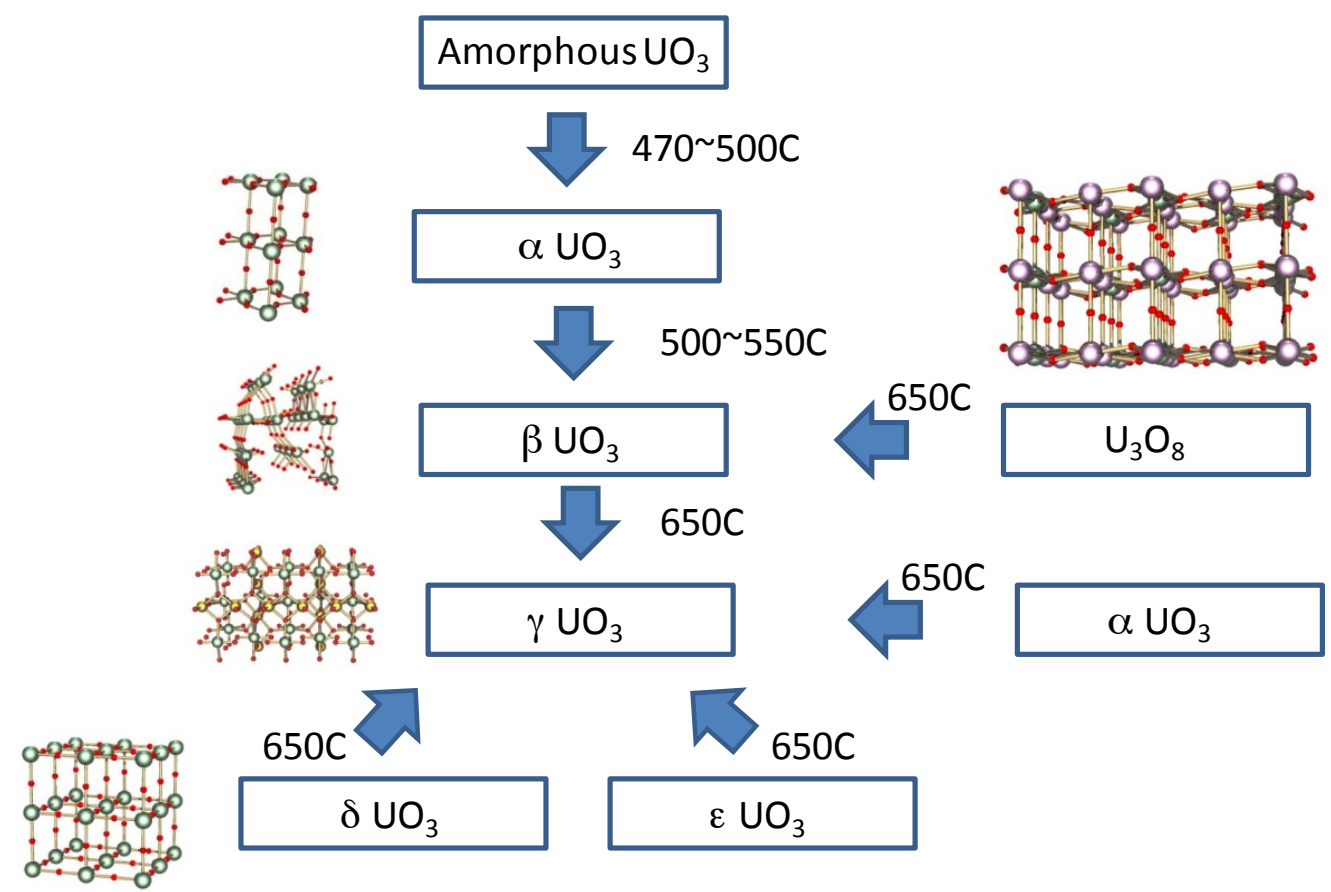

Figure 1: Flow sheet for the preparation of $\mathrm{UO}_{3}$ polymorphs. In the presence of oxygen, $\mathrm{UO}_{2}$ is oxidized to $\mathrm{U}_{3} \mathrm{O}_{8}$ whereas $\mathrm{UO}_{3}$ loses oxygen at temperatures greater than $500^{\circ} \mathrm{C}$ and is reduced to $\mathrm{U}_{3} \mathrm{O}_{8}$. See Table 4 for crystal structure unit cell parameters

\subsection{Experimental}

Our initial objective was to produce pure phases (confirmed by XRD) of three polymorphic species in order to start developing a validated spectral library for the $\mathrm{UO}_{3}$ system. The three starting materials chosen for this effort, included $\mathrm{UO}_{2}\left(\mathrm{NO}_{3}\right)_{2} \bullet 6 \mathrm{H}_{2} \mathrm{O},\left(\mathrm{NH}_{4}\right)_{4} \mathrm{UO}_{2}\left(\mathrm{CO}_{3}\right)_{3}$ and $\mathrm{UO}_{4} \bullet 2 \mathrm{H}_{2} \mathrm{O}$. Making $\mathrm{UO}_{3}$ from $\mathrm{UO}_{2}\left(\mathrm{NO}_{3}\right)_{2} \bullet 6 \mathrm{H}_{2} \mathrm{O}$ is commonly done when reprocessing spent fuel. Another potential route for producing $\mathrm{UO}_{3}$ during ore processing is through the precipitation and conversion from $\left(\mathrm{NH}_{4}\right)_{4} \mathrm{UO}_{2}\left(\mathrm{CO}_{3}\right)_{3}{ }^{7} \mathrm{UO}_{3}$ productions from $\mathrm{UO}_{4} \bullet 2 \mathrm{H}_{2} \mathrm{O}$ (meta-studtite or $\mathrm{UO}_{4} \cdot 2 \mathrm{H}_{2} \mathrm{O}$ studtite) is also common route of when processing and refining uranium from ores.

The $\left(\mathrm{NH}_{4}\right)_{4} \mathrm{UO}_{2}\left(\mathrm{CO}_{3}\right)_{3}$ used to make $\mathrm{UO}_{3}$ was prepared by adding $1.1965 \mathrm{~g}$ of $\left(\mathrm{NH}_{4}\right)_{2} \mathrm{CO}_{3}$ (SigmaAldrich $99.9 \%$ ) to $2.17 \mathrm{~mL}$ of a $0.96 \mathrm{M}$ aqueous solution of $\mathrm{UO}_{2}\left(\mathrm{NO}_{3}\right)_{2}$ (IBI 99.9\%). The yellow precipitate was allowed to settle and the water was decanted off. The wet solid was baked in a furnace at $80^{\circ} \mathrm{C}$ for $3 \mathrm{hrs}$ to remove the remaining water. A powder XRD pattern was collected to confirm the identity of the yellow powder product was $\left(\mathrm{NH}_{4}\right)_{4} \mathrm{UO}_{2}\left(\mathrm{CO}_{3}\right)_{3}$.

The $\mathrm{UO}_{2} \cdot 2 \mathrm{H}_{2} \mathrm{O}$ used to make $\mathrm{UO}_{3}$ was prepared by adding $3 \mathrm{~mL}$ of $30 \% \mathrm{H}_{2} \mathrm{O}_{2}$ (Sigma-Aldrich) to 5 $\mathrm{mL}$ of a $1 \mathrm{M}$ aqueous solution of $\mathrm{UO}_{2}\left(\mathrm{NO}_{3}\right)_{2}$ (IBI 99.9\%). A light yellow precipitate formed upon addition of the hydrogen peroxide. The solution was heated to $80^{\circ} \mathrm{C}$ for 24 hours to dry the sample. Powder XRD of the final product confirmed the light yellow powder was $\mathrm{UO}_{2} \cdot 2 \mathrm{H}_{2} \mathrm{O}$.

Separate samples of $\mathrm{UO}_{2}\left(\mathrm{NO}_{3}\right)_{2} \bullet 6 \mathrm{H}_{2} \mathrm{O},\left(\mathrm{NH}_{4}\right)_{4} \mathrm{UO}_{2}\left(\mathrm{CO}_{3}\right)_{3}$ and $\mathrm{UO}_{2} \bullet 2 \mathrm{H}_{2} \mathrm{O}$ were individually heated to a variety of different temperatures ranging from $350^{\circ} \mathrm{C}$ to $500^{\circ} \mathrm{C}$ for $60 \mathrm{hrs}$. Powder XRD patterns were collected on all starting materials and products using a Rigaku Ultima IV powder diffractometer equipped with a monochromated $\mathrm{Cu} \mathrm{K}$ source and a D/Tex silicon strip detector. The samples were also analyzed using an ExamineR 785 Raman spectrometer (Delta-Nu) attached to an Olympus BX51 compound 
microscope. In addition samples were analyzed using a PARISS fluorescence spectrometer attached to a Nikon Eclipse 50i microscope.

In addition to exploring the formation of $\mathrm{UO}_{3}$ we also explored the formation of hydrolysis products formed under ambient conditions (humid air at room temperature). The two common hydrolysis products of $\mathrm{UO}_{3}$ are $\alpha-\mathrm{UO}_{2}(\mathrm{OH})_{2}$ and $\left(\mathrm{UO}_{2}\right)_{4} \mathrm{O}(\mathrm{OH})_{6} \cdot 5 \mathrm{H}_{2} \mathrm{O}$ (meta-scheopite). Pure $\alpha-\mathrm{UO}_{2}(\mathrm{OH})_{2}$ was prepared by submerging a sample of $\gamma-\mathrm{UO}_{3}$ in water and then heating it to $80^{\circ} \mathrm{C}$ for $24 \mathrm{hrs}$ to drive off the excess water (the water that did not get involved in the reaction). $\left(\mathrm{UO}_{2}\right)_{4} \mathrm{O}(\mathrm{OH})_{6} \cdot 5 \mathrm{H}_{2} \mathrm{O}$, a more hydrated form, was prepared by submerging a sample of $\gamma-\mathrm{UO}_{3}$ in water and allowing the water to evaporate a room temperature. These samples were analyzed using XRD, Raman microscopy and fluorescence microscopy. The dehydration of $\alpha-\mathrm{UO}_{2}(\mathrm{OH})_{2}$ (from a hydration dehydration stand point can be written as $\mathrm{UO}_{3} \bullet \mathrm{H}_{2} \mathrm{O}$ ) was also followed using a Q20 differential scanning calorimeter (DSC) made by TA instruments. The DSC experiment was conducted under a $3^{\circ} \mathrm{C} / \mathrm{min}$ ramp rate and a $5 \mathrm{~mL} / \mathrm{min} \mathrm{N}_{2}$ flow rate.

\subsection{Phase Field Model}

We hypothesize that the nucleation process might control the volume fraction of $\alpha-, \beta-, \gamma-\mathrm{UO}_{3}$ during the genesis from amorphous $\mathrm{UO}_{3}$ to crystal $\mathrm{UO}_{3}$. Phase-field model has been widely used to predict the microstructure evolution during phase transitions. Since the driving forces and barriers of phase transitions, such as chemical free energy, interfacial energy and elastic energy, are taken into account in the phase-field model, the model can capture the nucleation process. First we consider amorphous $\mathrm{UO}_{3}$ to orthorhombic ( $\alpha$ phase) transition. Eight variables: one composition $c(\mathbf{r}, t)$ describing $\mathrm{O}$ concentration; six order parameters $\eta_{i}(\mathbf{r}, t), i=1, \ldots, 6$ describing six orientational varients of $\alpha$ phase, and one order parameter $\phi(\mathbf{r})$ describing gas phase, are used to describe the microstructure of the system. In phase-field framework, the total free energy of the system including chemical free energy, interfacial energy and elastic energy is described as

$$
F=\iiint_{\Omega}\left[f\left(c, \phi, \eta_{i}, T\right)+\sum_{i, j} \frac{\kappa_{i j}}{2}\left|\nabla \eta_{i}\right|\left|\nabla \eta_{j}\right|+\frac{1}{2} \lambda_{i j k l} \varepsilon_{i j}^{e l} \varepsilon_{k l}^{e l}\right] d V
$$

where $f\left(c, \phi, \eta_{\alpha \beta}, T\right)$ is the chemical free energy. The second term is gradient energy. The coefficients $\kappa_{i j}$ are determined by anisotropic interfacial energies and interface thickness. The last term is the elastic energy associated the volume and shape change during the phase transition. $T$ is the temperature. $\lambda_{i j k l}$ is the elastic constant, and $\varepsilon_{i j}^{e l}$ is the elastic strain tensor. The microstructure evolution is governed by the Cahn Hilliard equation for concentration $c(\mathbf{r}, t)$ and Allen Cahn equations for the order parameters $\eta_{i}(\mathbf{r}, t)$ :

$$
\begin{aligned}
& \frac{\partial c(\mathbf{r}, t)}{\partial t}=\nabla M \cdot \nabla \frac{\delta F}{\delta c}+\xi(\mathbf{r}, t), \\
& \frac{\partial \eta_{i}(\mathbf{r}, t)}{\partial t}=-L \frac{\delta F}{\delta \eta_{i}}+\varsigma_{i}(\mathbf{r}, t),
\end{aligned}
$$

where $\mathrm{M}$ is $\mathrm{O}$ mobility, $\mathrm{L}$ is the interface mobility, $\xi(\mathbf{r}, t)$ and $\zeta_{i}(\mathbf{r}, t)$ are the thermal fluctuation. For a given material process such as initial structure, concentration, and temperature, solving the equations will give the concentration and structure change with time, hence, the transition kinetics. 


\subsection{Results and Discussion}

\section{$3.1 \mathrm{Y}-\mathrm{UO}_{3}$}

The first system we explored was the conversion of $\mathrm{UO}_{2}\left(\mathrm{NO}_{3}\right)_{2} \bullet 6 \mathrm{H}_{2} \mathrm{O}$ to $\gamma-\mathrm{UO}_{3}$ After heating $1 \mathrm{~g}$ of $\mathrm{UO}_{2}\left(\mathrm{NO}_{3}\right)_{2} \cdot 6 \mathrm{H}_{2} \mathrm{O}$ at $350^{\circ} \mathrm{C}$ for $60 \mathrm{hrs}$ the XRD powder pattern of the orange powder sample matched that of $\gamma-\mathrm{UO}_{3}$ (Figure 2). The sample was allowed to sit in a vial at room temperature for 5 days. The sample was analyzed by powder XRD again to see if any hydrolysis products had formed. As seen in Figure 2, there was no indication of a hydrolysis product or ingrowth of a different phase after 5 days time. The sample was then heated at $400^{\circ} \mathrm{C}$ for $60 \mathrm{hrs}$. The XRD powder pattern of the sample after heating at $400^{\circ} \mathrm{C}$ still appears to be of the $\gamma-\mathrm{UO}_{3}$ phase (shown in Figure 4). This behavior is consistent with what has been previously reported in the literature. ${ }^{2}$ Having a pure sample of $\gamma-\mathrm{UO}_{3}$ will be useful for understanding the optical spectral. The Raman spectrum of the pure $\gamma-\mathrm{UO}_{3}$ sample is shown in Figure 3 and the fluorescence spectrum is shown in Figure 4.

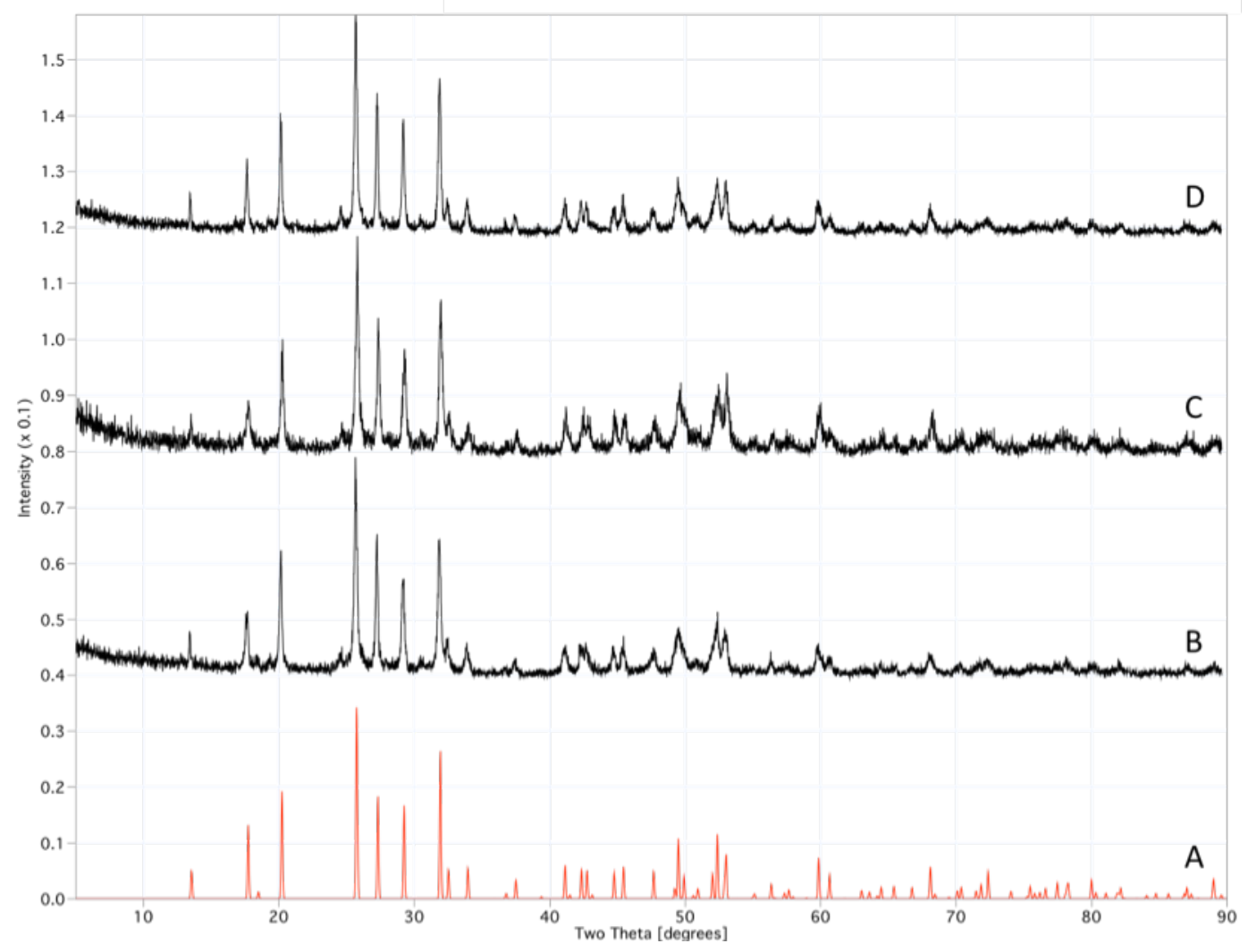

Figure 2: Calculated XRD powder pattern from crystal structure of $\gamma-\mathrm{UO}_{3}(\mathrm{~A}), \mathrm{XRD}$ powder pattern of sample of $\mathrm{UO}_{2}\left(\mathrm{NO}_{3}\right)_{2} \bullet 6 \mathrm{H}_{2} \mathrm{O}$ heated to $350^{\circ} \mathrm{C}$ for 60 hours (B), XRD powder pattern of same sample after 5 days at room temperature (C), XRD powder pattern of same sample after heating it to $400^{\circ} \mathrm{C}$ for 60 hours (D).

$\mathrm{UO}_{3}$ is known to form hydrolysis products under ambient conditions (humid air at room temperature). The resulting Raman and fluorescence spectra for the pure phases of $\alpha-\mathrm{UO}_{2}(\mathrm{OH})_{2}$ and 
$\left(\mathrm{UO}_{2}\right)_{4} \mathrm{O}(\mathrm{OH})_{6} \cdot 5 \mathrm{H}_{2} \mathrm{O}$ prepared are shown in Figures 3 and 4 respectively. While the distinction between the spectra of $\gamma-\mathrm{UO}_{3}$ and the hydrolysis products is clear, the distinction between the two hydrolysis products is less clear. The collection of the XRD patterns took 30 minutes per sample where as the collection of the optical spectra took 1 minute per sample for Raman and 1 second per sample for the fluorescence spectra. Here we have demonstrated two techniques (Raman and fluorescence spectrosocpies) that can more rapidly identify hydrolysis products of $\mathrm{UO}_{3}$.

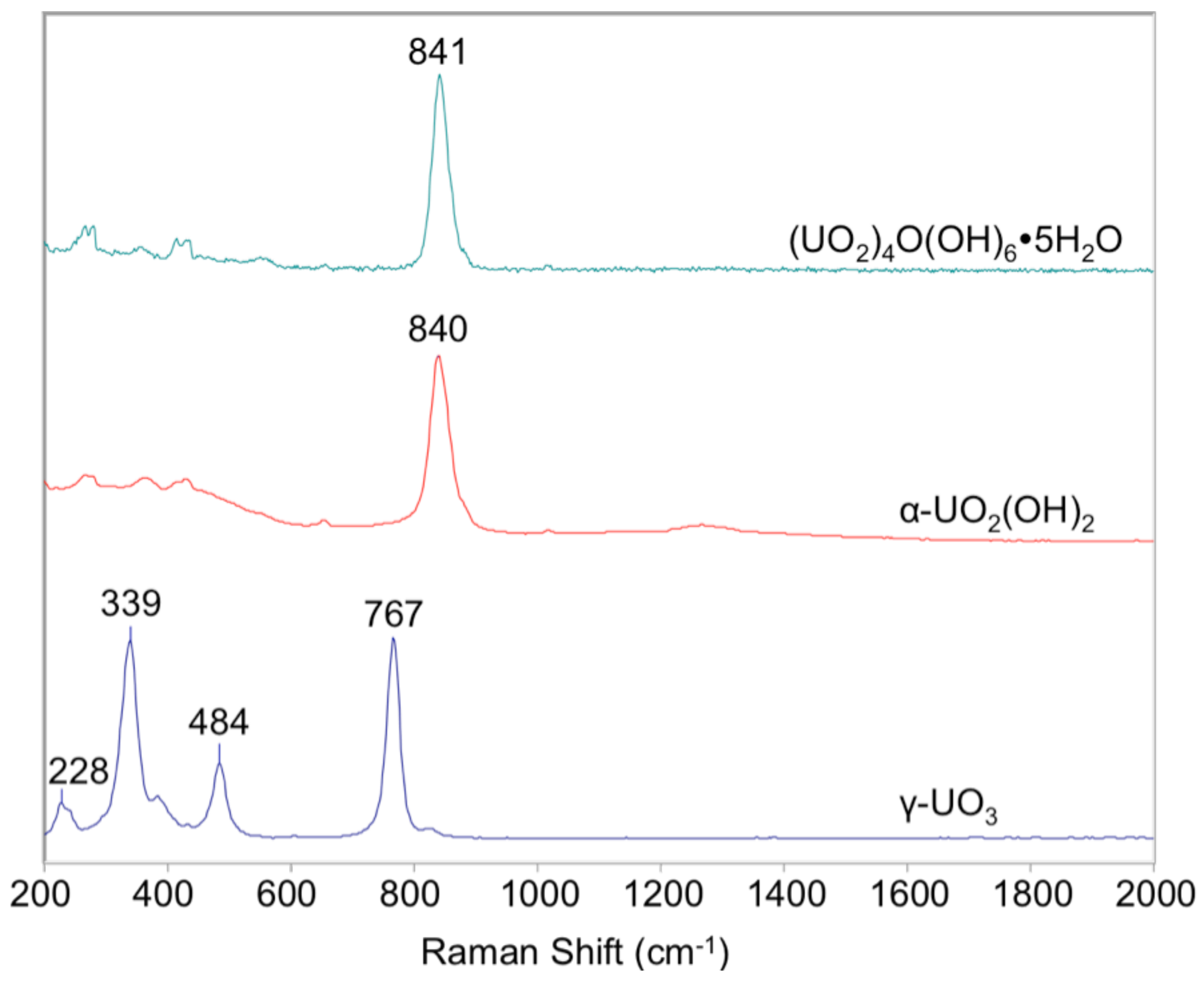

Figure 3: Raman spectra of $\gamma-\mathrm{UO}_{3}, \alpha-\mathrm{UO}_{2}(\mathrm{OH})_{2}$ and $\left(\mathrm{UO}_{2}\right)_{4} \mathrm{O}(\mathrm{OH})_{6} \cdot 5 \mathrm{H}_{2} \mathrm{O}$. 


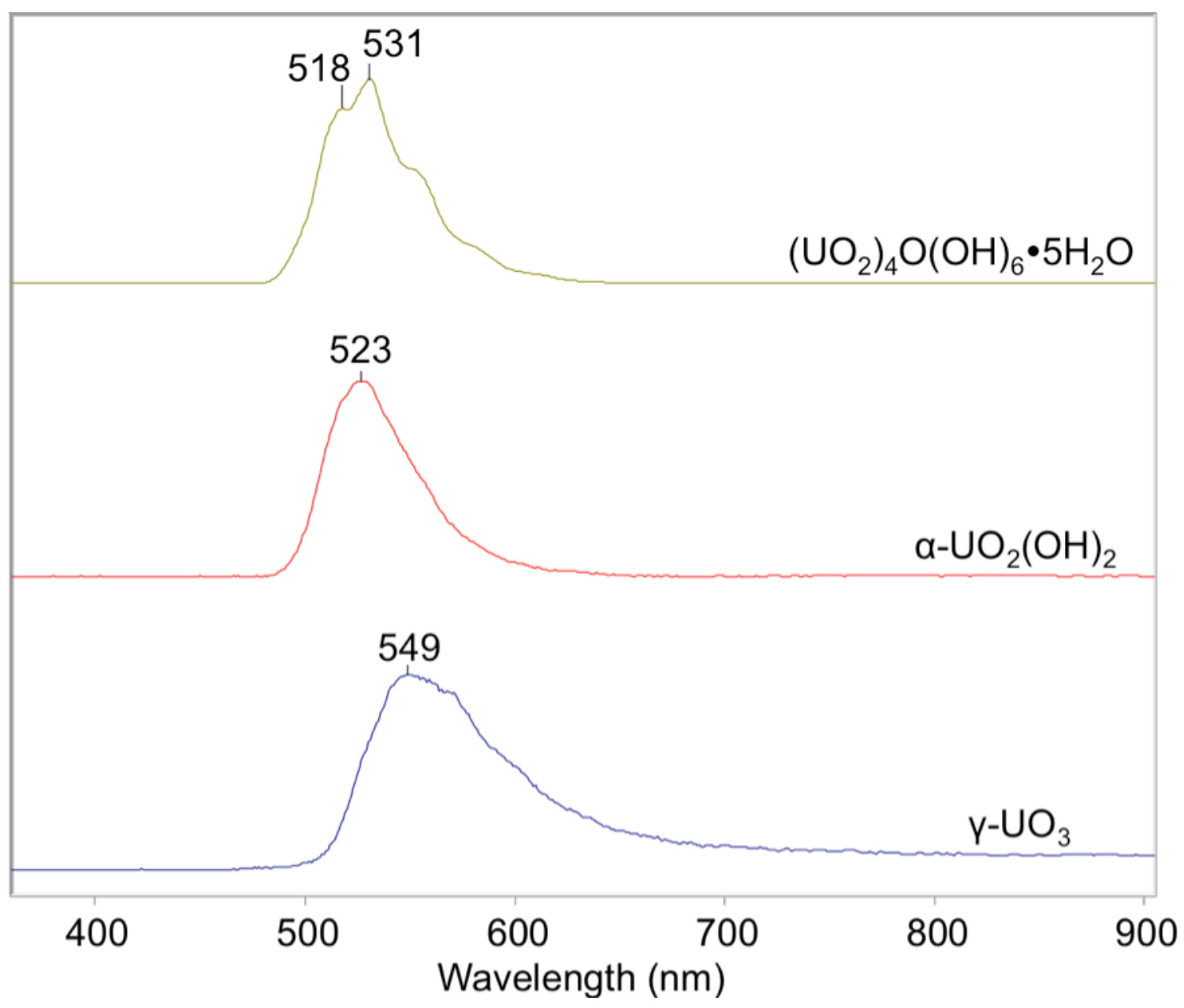

Figure 4: Fluorescence spectrum of $\gamma-\mathrm{UO}_{3}, \alpha-\mathrm{UO}_{2}(\mathrm{OH})_{2}$ and $\left(\mathrm{UO}_{2}\right)_{4} \mathrm{O}(\mathrm{OH})_{6} \cdot 5 \mathrm{H}_{2} \mathrm{O}$ excited with $375 \mathrm{~nm}-425 \mathrm{~nm}$ light.

The degree of hydrolysis of $\mathrm{UO}_{3}$ may be used as a chronometer. While we did not set up experiments to rigorously determine the rate of hydrolysis of $\mathrm{UO}_{3}$ under any set of controlled conditions, we did analyze generated samples of $\mathrm{UO}_{3}$ over time. A sample of $\gamma-\mathrm{UO}_{3}$, initially made pure and confirmed by XRD, was analyzed by again by XRD after sitting in a capped vial for 34 days. The resulting XRD powder pattern, shown in Figure 5, indicates that the composition was $25 \% \alpha-\mathrm{UO}_{2}(\mathrm{OH})_{2}$ and $75 \% \gamma-\mathrm{UO}_{3}$ 34 days after production. More work is needed to define a hydrolysis rate under a variety of different conditions. Also interesting to investigate would be to see how temperature and humidity on the ratio of $\left(\mathrm{UO}_{2}\right)_{4} \mathrm{O}(\mathrm{OH})_{6} \bullet 5 \mathrm{H}_{2} \mathrm{O}$ to $\alpha-\mathrm{UO}_{2}(\mathrm{OH})_{2}$. Temperature, humidity and time are the key factors that determine the degree of hydrolysis of $\mathrm{UO}_{3}$ 


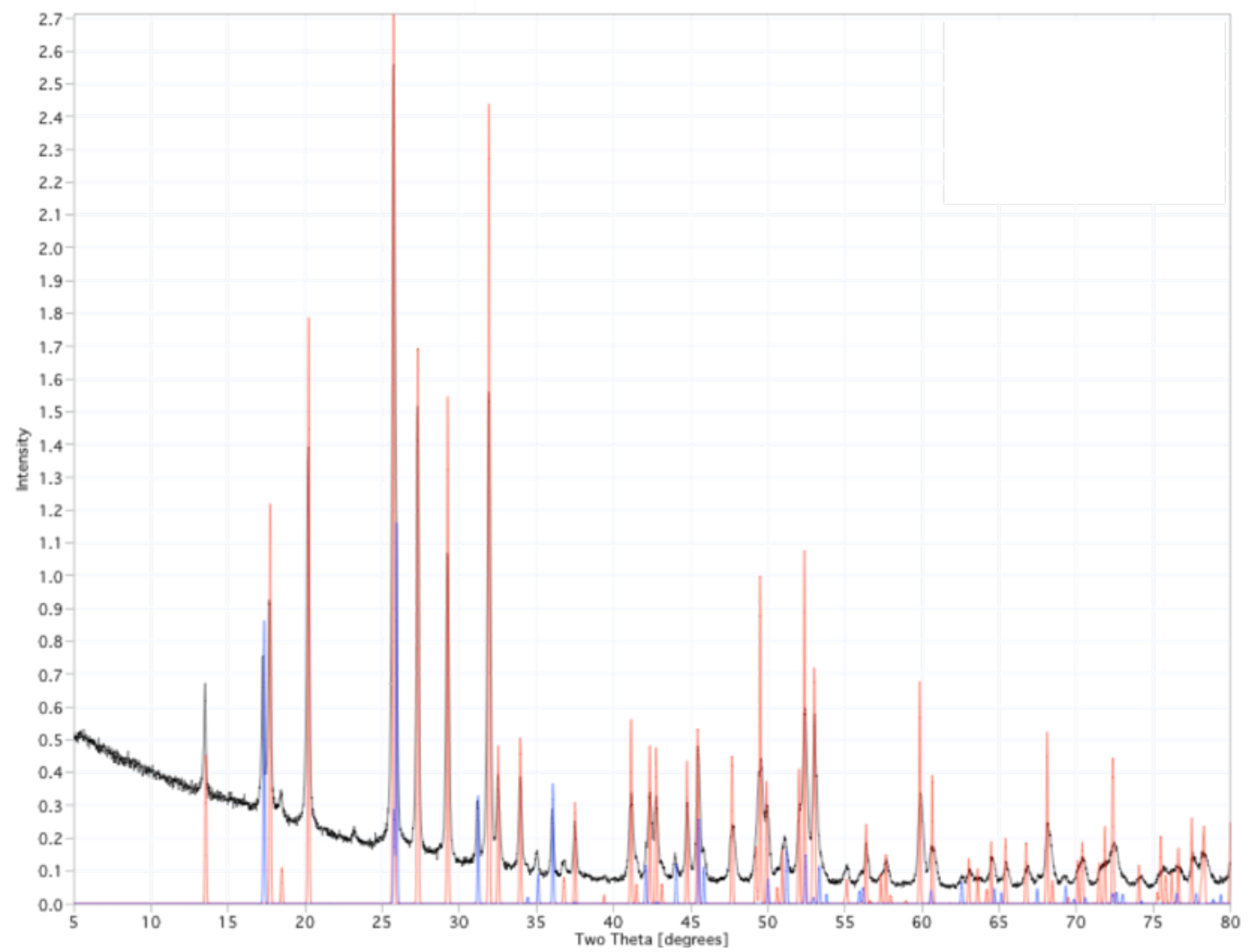

Figure 5: XRD powder pattern of a pure $\gamma-\mathrm{UO}_{3}$ sample that was stored in a capped vial for 34 days (black pattern). The product was $75 \% \gamma-\mathrm{UO}_{3}$ (calculated red pattern), $25 \% \alpha-\mathrm{UO}_{2}(\mathrm{OH})_{2}$ (calculated blue pattern).

The hydrolysis of $\mathrm{UO}_{3}$ can be reversed by heating the sample back up to $450^{\circ} \mathrm{C}$ for 3 hours. This process was followed by XRD, shown in Figure 6. To get a better understanding of the temperature dependent water loss the process was also monitored using differential scanning calorimetry (DSC), shown in Figure 7. The major endothermic peak at $380^{\circ} \mathrm{C}$ indicates this might be the temperature at which $\alpha-\mathrm{UO}_{2}(\mathrm{OH})_{2}$ dehydrates. More work needs to be done in order to determine the species that are formed after each observed endotherm. 


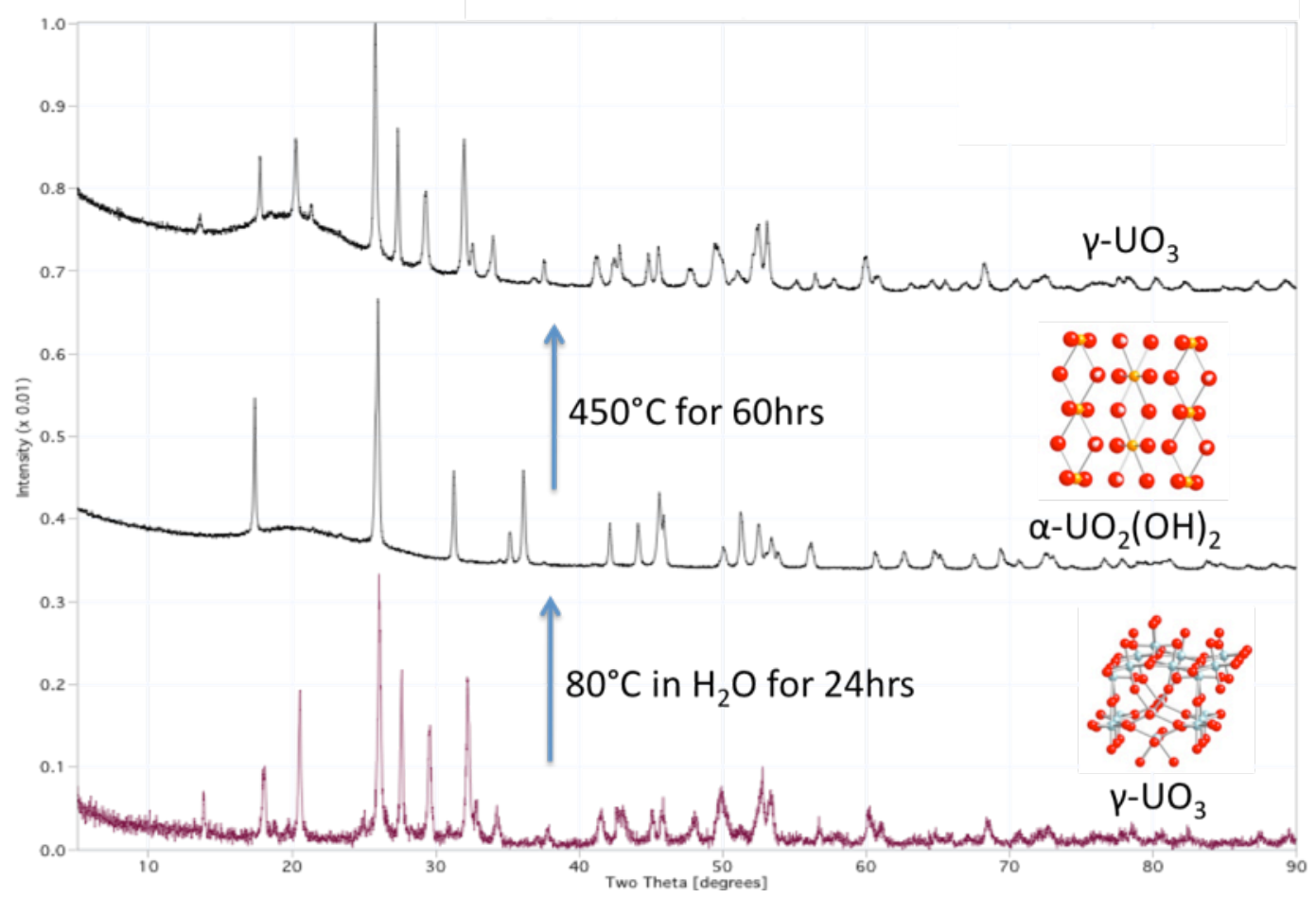

Figure 6: A sample of freshly prepared $\gamma-\mathrm{UO}_{3}$ (bottom pattern) was hydrolyzed to $\alpha-\mathrm{UO}_{2}(\mathrm{OH})_{2}$ (middle pattern) and then dehydrated back to $\gamma-\mathrm{UO}_{3}$ (top pattern).

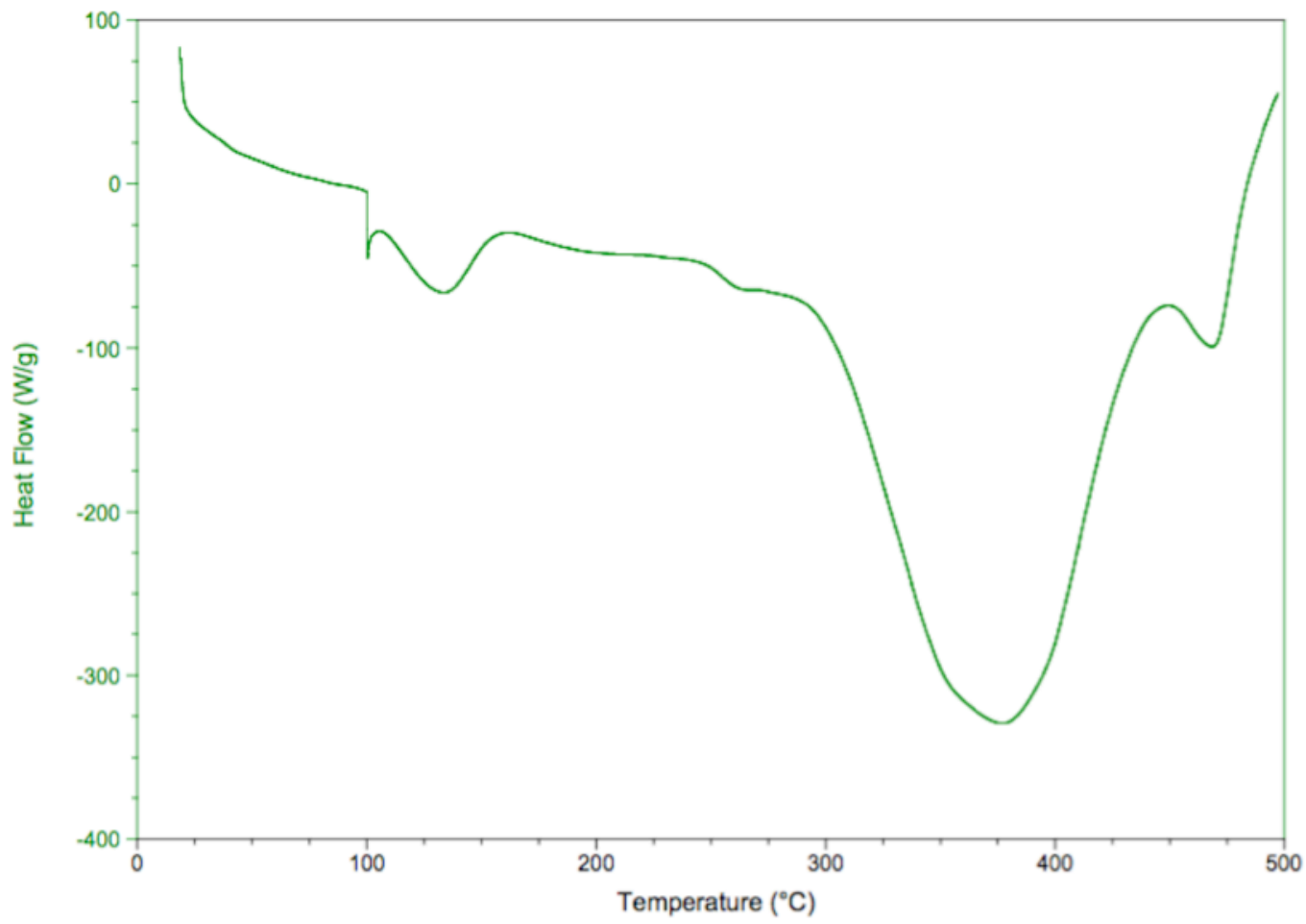

Figure 7: DSC spectrum of $\alpha-\mathrm{UO}_{2}(\mathrm{OH})_{2}$. 


\section{2 $\mathrm{UO}_{3}$ from $\left(\mathrm{NH}_{4}\right)_{4} \mathrm{UO}_{2}\left(\mathrm{CO}_{3}\right)_{3}$}

Surprising results came from the preparation of $\mathrm{UO}_{3}$ using $\left(\mathrm{NH}_{4}\right)_{4} \mathrm{UO}_{2}\left(\mathrm{CO}_{3}\right)_{3}$. A similar approach was taken with $\left(\mathrm{NH}_{4}\right)_{4} \mathrm{UO}_{2}\left(\mathrm{CO}_{3}\right)_{3}$ as was $\mathrm{UO}_{2}\left(\mathrm{NO}_{3}\right)_{2}$ in that a series of preparation temperatures were tried. Figure 8 shows the XRD patterns and Raman spectra that resulted from the sequential heating of a sample that began as $\left(\mathrm{NH}_{4}\right)_{4} \mathrm{UO}_{2}\left(\mathrm{CO}_{3}\right)_{3}$. Our initial hope was to make a pure sample a amorphous $\mathrm{UO}_{3}$ from $\left(\mathrm{NH}_{4}\right)_{4} \mathrm{UO}_{2}\left(\mathrm{CO}_{3}\right)_{3}$ after heating to $400^{\circ} \mathrm{C}$ (see table 1). As shown in Figure 9 the product that formed after heating the sample to $350^{\circ} \mathrm{C}$ and $400^{\circ} \mathrm{C}$ was a mix of an amorphous species and $\beta-\mathrm{UO}_{3}$. This is a previously unknown route to $\beta-\mathrm{UO}_{3}$ production. After heating the sample to $450^{\circ} \mathrm{C}$ a mixture of $\alpha$ - and $\beta-\mathrm{UO}_{3}$ was produced as shown in Figure 10. This rather complicated system is a prime candidate for the development of a phase field model. Understanding the production of $\mathrm{UO}_{3}$ from $\left(\mathrm{NH}_{4}\right)_{4} \mathrm{UO}_{2}\left(\mathrm{CO}_{3}\right)_{3}$ could lead to many relevant signatures for determining the history of a sample. More work needs to be done in order to assign the observed peaks in the Raman spectra to the forms of $\mathrm{UO}_{3}$ present. Raman spectroscopic analysis would be a more rapid characterization technique than XRD. In addition Raman spectroscopy has the potential of detecting the presence of amorphous phases.
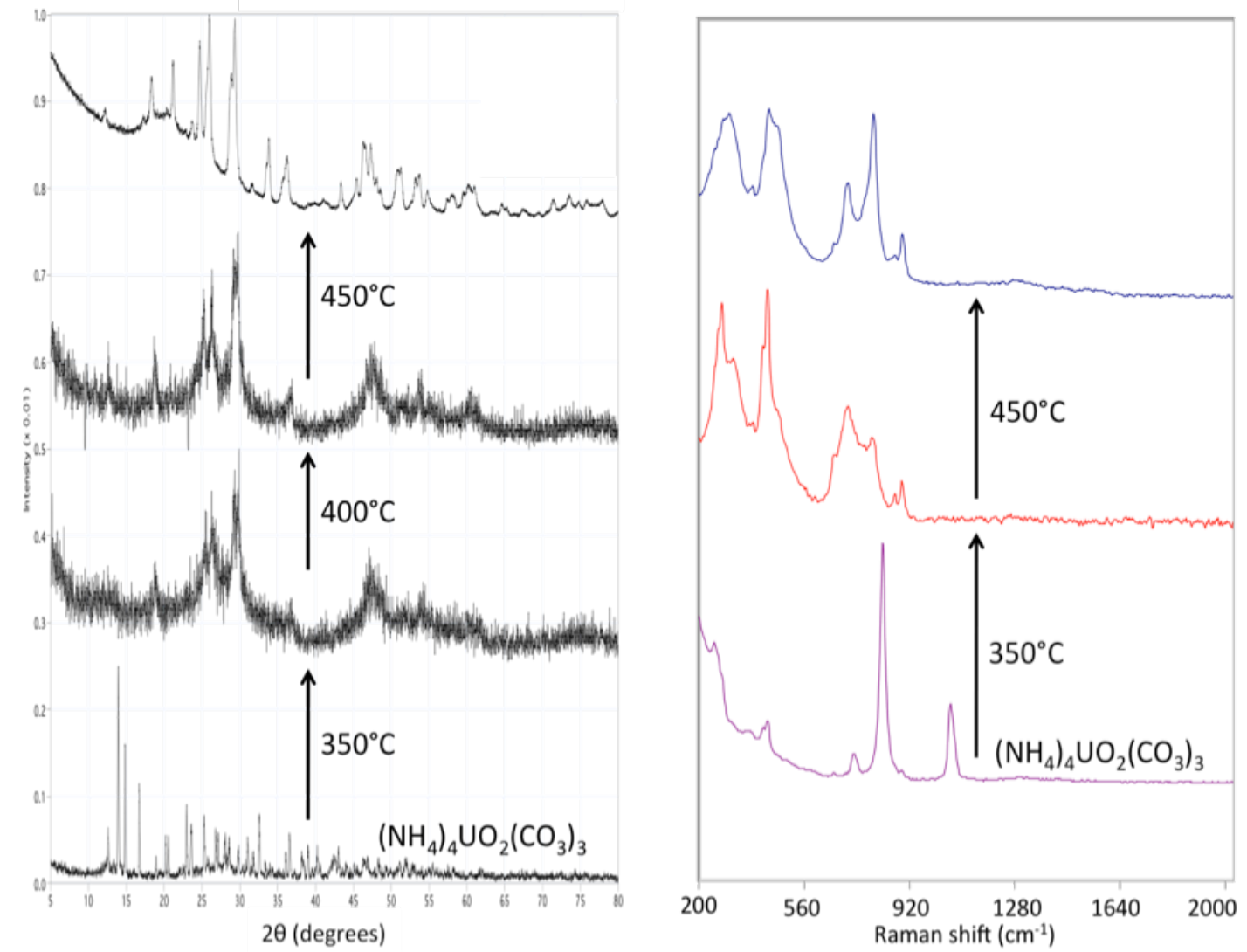

Figure 8: Powder XRD patterns (left) and Raman spectra (right) of the products that are formed after heating $\left(\mathrm{NH}_{4}\right)_{4} \mathrm{UO}_{2}\left(\mathrm{CO}_{3}\right)_{3}$ to increasingly higher temperatures. 


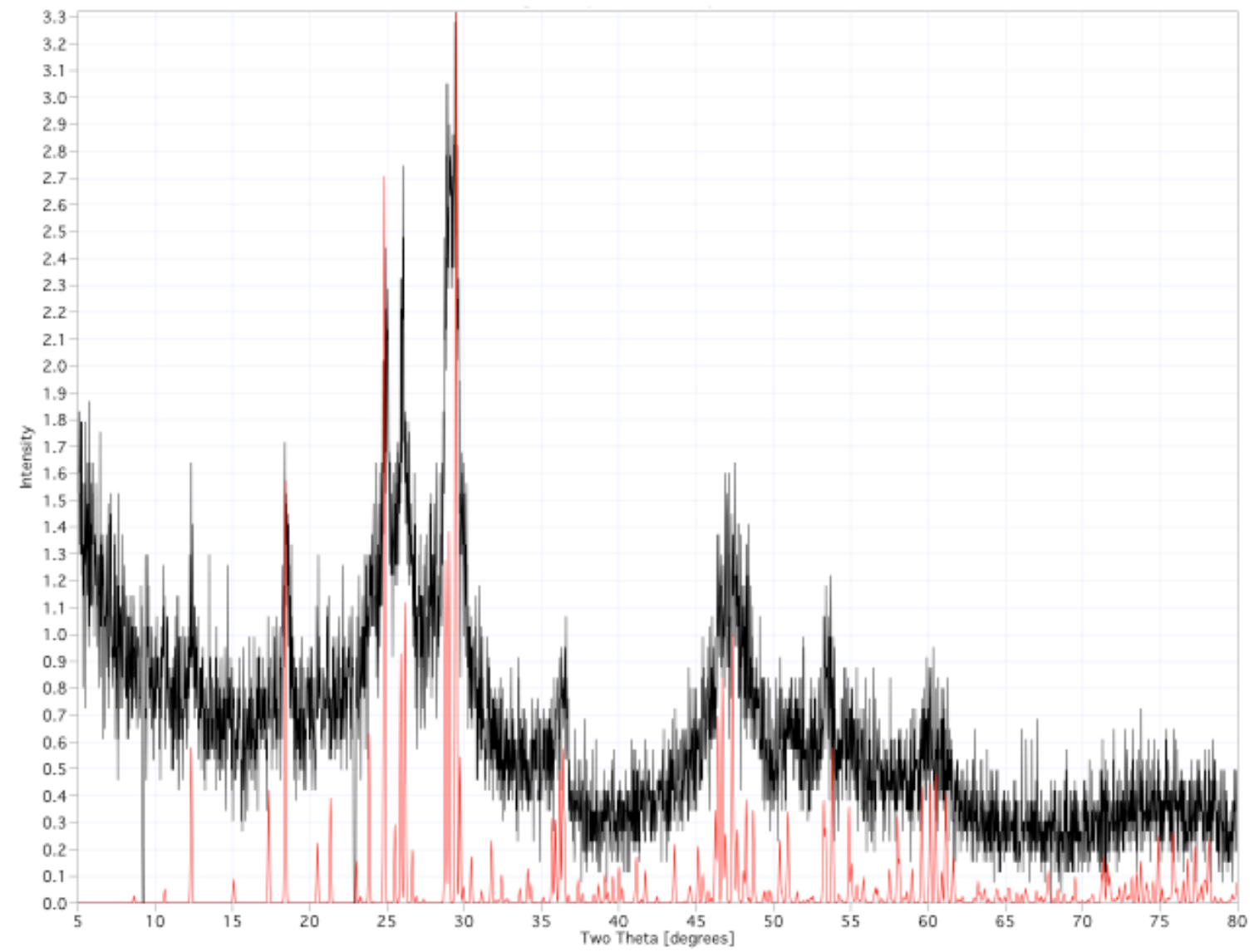

Figure 9: The black pattern is of a sample of $\left(\mathrm{NH}_{4}\right)_{4} \mathrm{UO}_{2}\left(\mathrm{CO}_{3}\right)_{3}$ that was heated to $400^{\circ} \mathrm{C}$ for 60 hours. The red pattern was calculated from the crystal structure of $\beta-\mathrm{UO}_{3}$. 


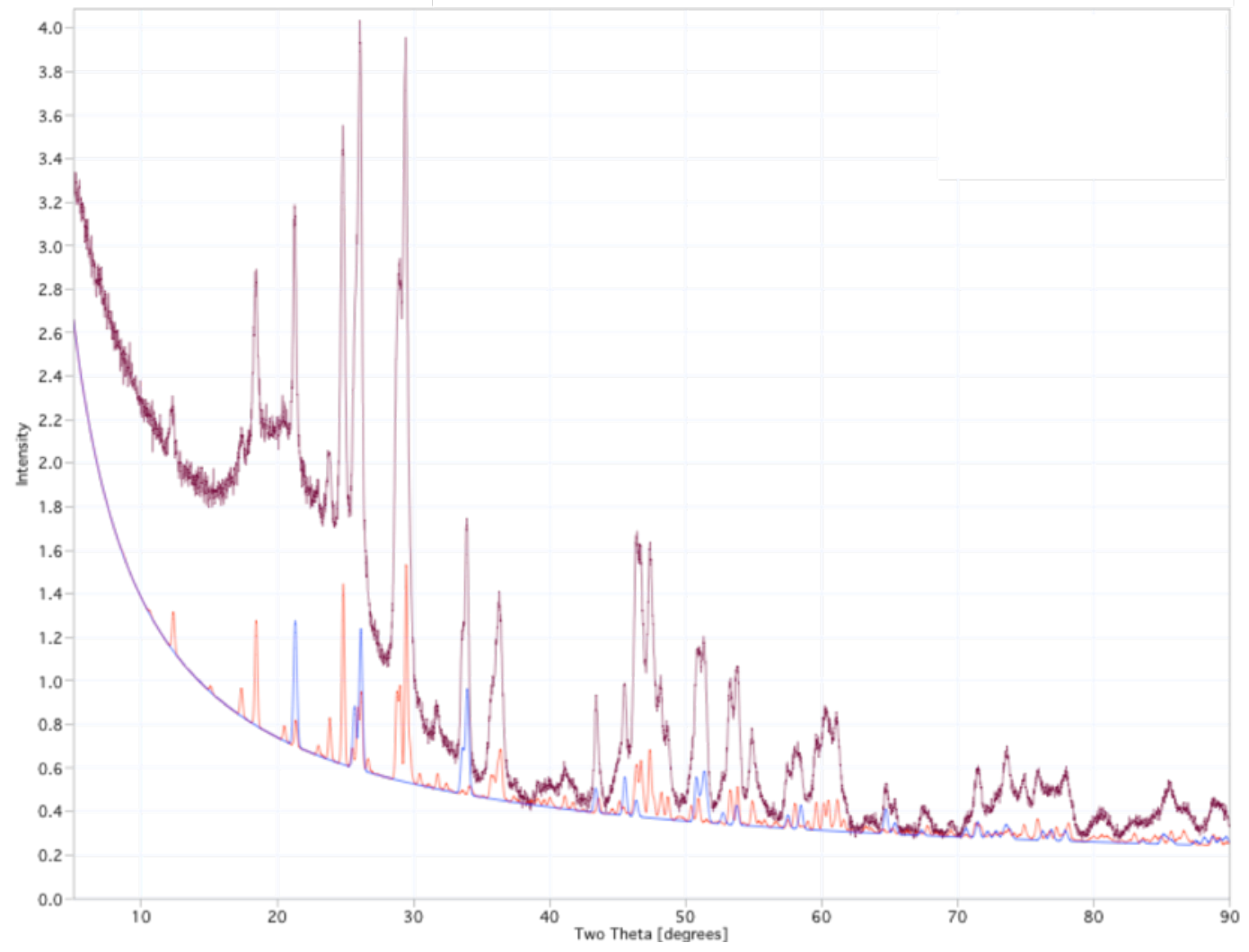

Figure 10: Powder XRD pattern of the product after $\left(\mathrm{NH}_{4}\right)_{4} \mathrm{UO}_{2}\left(\mathrm{CO}_{3}\right)_{3}$ was heated to $500^{\circ} \mathrm{C}$ for $60 \mathrm{hrs}$ (black). The blue and red patterns were calculated from the crystal structures of $\alpha-\mathrm{UO}_{3}$ and $\beta-\mathrm{UO}_{3}$ respectively. The relative composition was $33 \% \alpha-\mathrm{UO}_{3}$ and $67 \% \beta-\mathrm{UO}_{3}$.

\section{$3.3 \alpha-\mathrm{UO}_{3}$}

A sample of $\alpha-\mathrm{UO}_{3}$ was prepared by heating meta-studtite. In small scale preparations $(\sim 1 \mathrm{~g}) \alpha-\mathrm{UO}_{3}$ can be made clean (according to XRD see Figure 11).

We could not obtain a Raman spectrum of $\alpha-\mathrm{UO}_{3}$ using the $785 \mathrm{~nm}$ laser. The bulk of the $\alpha-\mathrm{UO}_{3}$ did not fluoresce in the visible/near IR region when exposed to excitation bands ranging from 375-560 nm. Interestingly, small particles of meta-studtite and $\alpha-\mathrm{UO}_{2}(\mathrm{OH})_{2}$ could be observed in a product that was thought to be pure based on the powder XRD pattern. In Figure 12 the bright spots circled and labeled A and $\mathrm{B}$ are results of fluorescence. With the micofluorescence technique developed by a PNNL LDRD project we were able to identify the fluorescing species in the sample. The spectrum of A (see Figure 12) matches the spectrum of $\alpha-\mathrm{UO}_{2}(\mathrm{OH})_{2}$ obtained earlier (see Figure 4). The spectrum of B (see Figure 12) matches the spectrum of $\mathrm{UO}_{4} \cdot 2 \mathrm{H}_{2} \mathrm{O}$, which is the starting material. While we could not get any spectroscopic data from the $\alpha-\mathrm{UO}_{3}$ phase itself, we were able to use the spectroscopic library we have established to identify small quantities of impurities. 


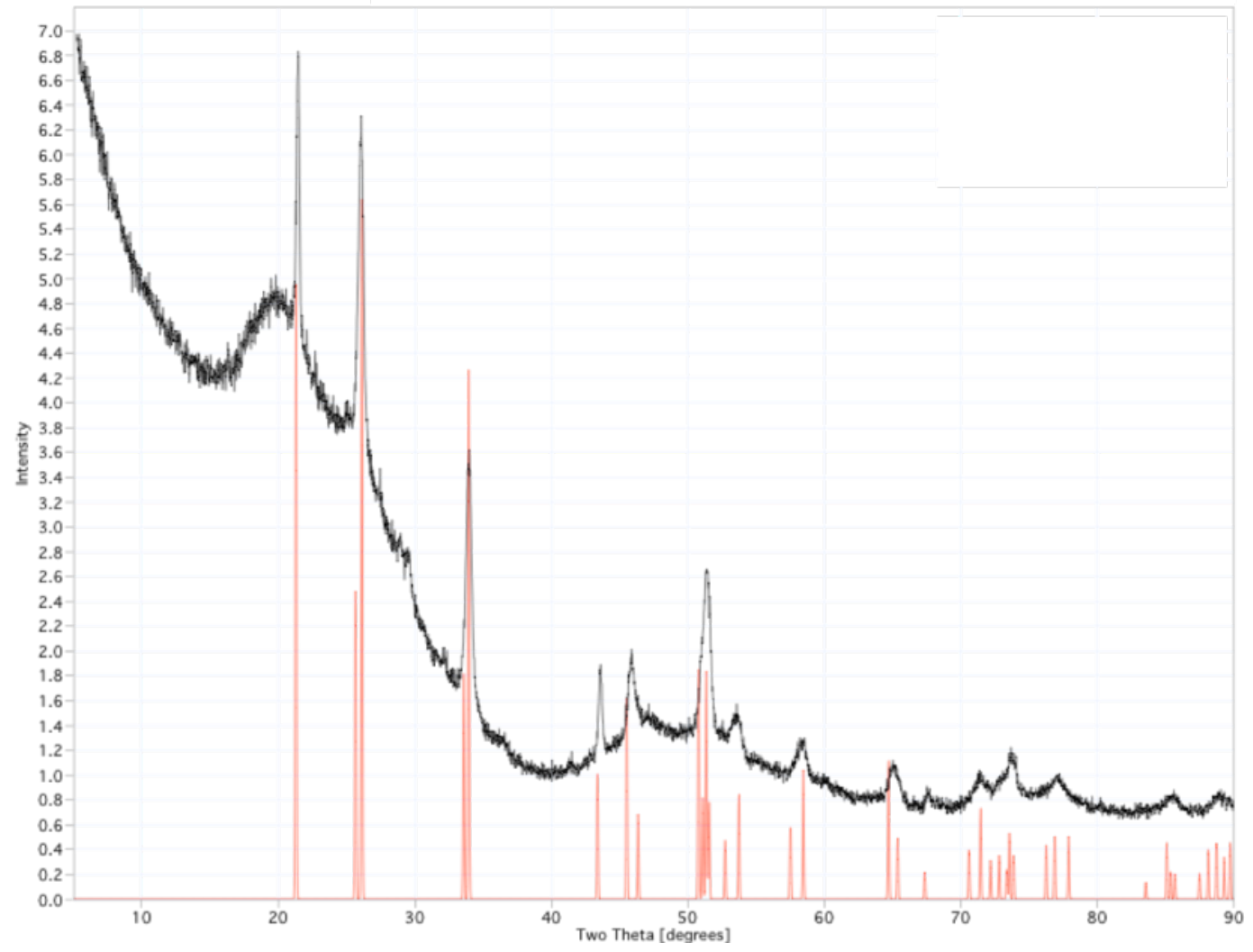

Figure 11: Powder XRD pattern of a sample of $\alpha-\mathrm{UO}_{3}$ prepared by heating $\mathrm{UO}_{4} \cdot 2 \mathrm{H}_{2} \mathrm{O}$ to $400^{\circ} \mathrm{C}$ for $60 \mathrm{hrs}$ (black). The red XRD pattern was calculated from the crystal structure of $\alpha-\mathrm{UO}_{3}$.

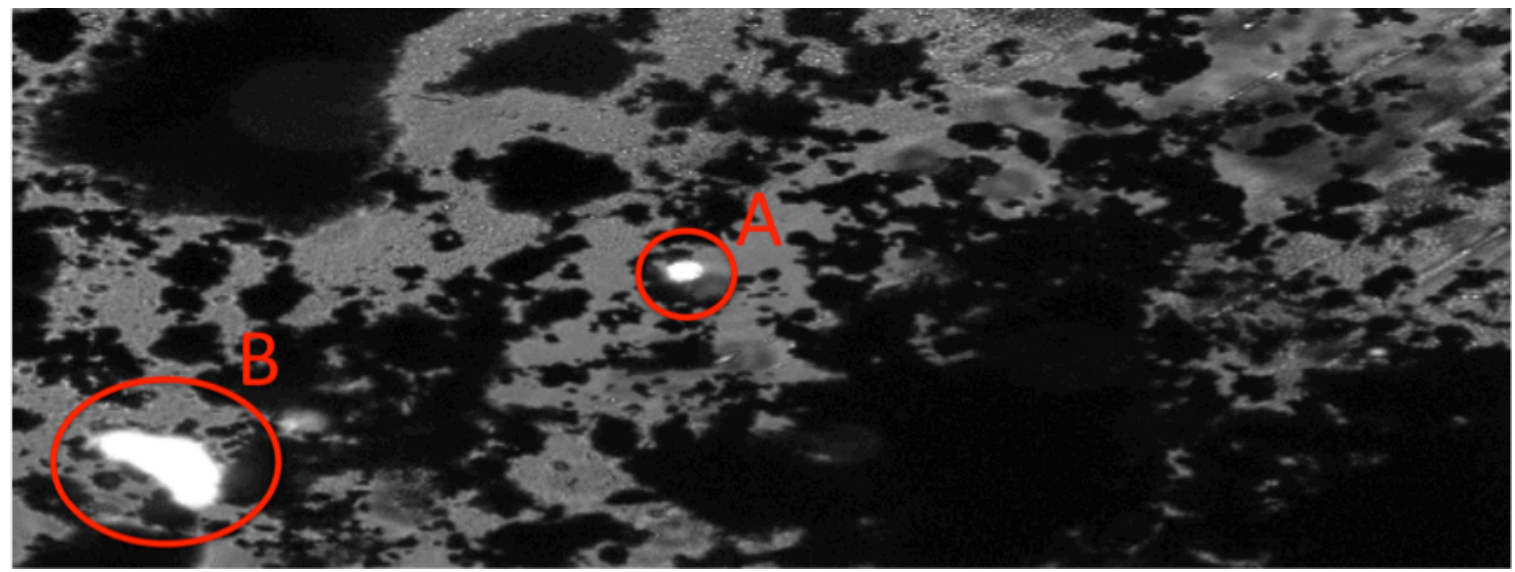



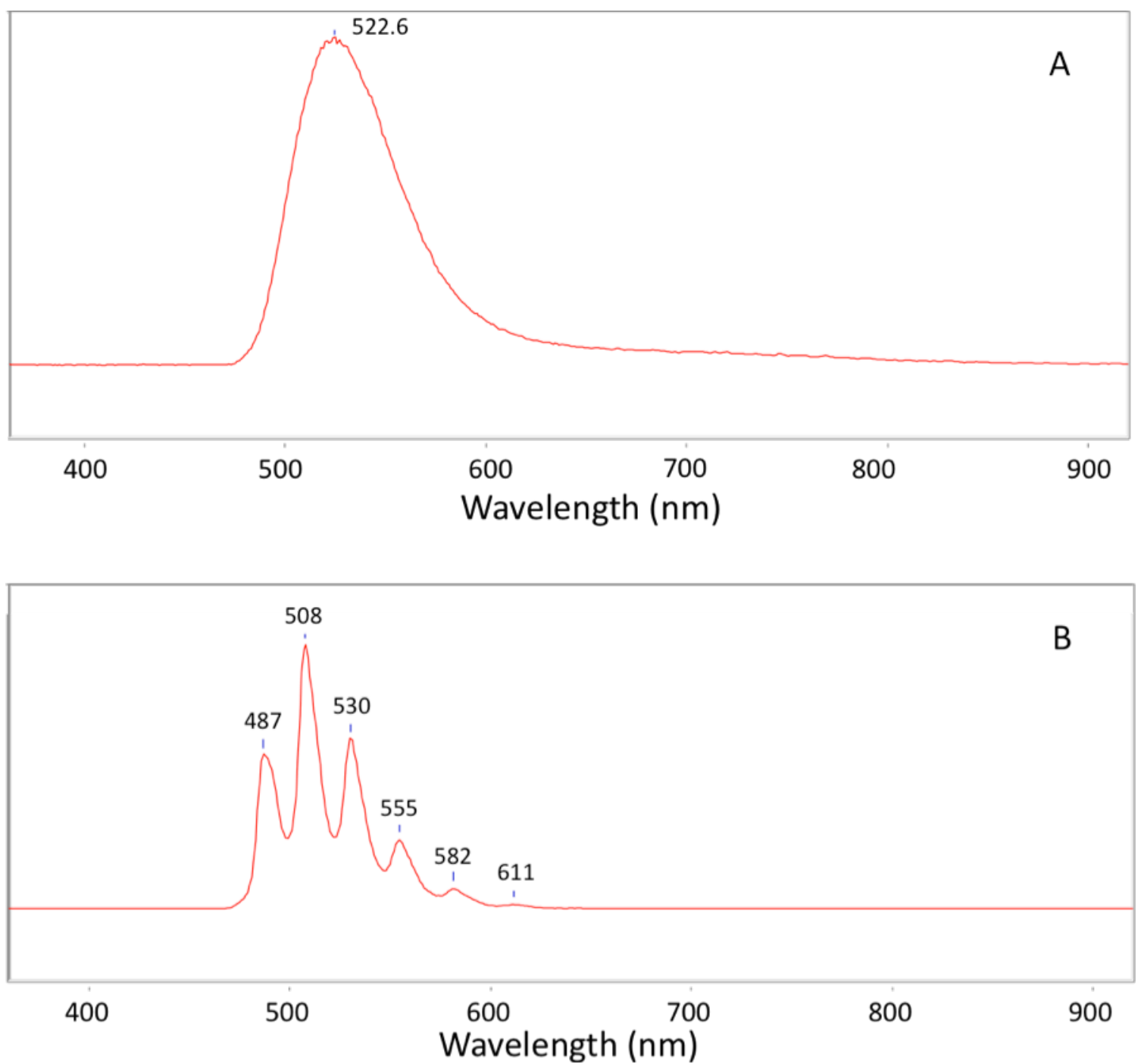

Figure 12. Picture of $\alpha-\mathrm{UO}_{3}$ sample through a 10x optical microscope (top). The bright spots circled and labeled as A and B are a result of fluorescence from a $375 \mathrm{~nm}-425 \mathrm{~nm}$ illumination source. The fluorescence spectrum of these two particles are shown below and labeled with the corresponding A and B labels. The spectrum of particle A matches that of $\alpha-\mathrm{UO}_{2}(\mathrm{OH})_{2}$. The spectrum of particle B matches that of $\mathrm{UO}_{4} \bullet 2 \mathrm{H}_{2} \mathrm{O}$.

The sample of $\alpha-\mathrm{UO}_{3}$ was also allowed to age in a capped vial for 45 days. From the resulting powder XRD pattern, shown in Figure 13, it was determined that the sample consisted of $90 \% \alpha-$ $\mathrm{UO}_{2}(\mathrm{OH})_{2}, 5 \% \alpha-\mathrm{UO}_{3}$ and $5 \%\left(\mathrm{UO}_{2}\right)_{4} \mathrm{O}(\mathrm{OH})_{6} \cdot 5 \mathrm{H}_{2} \mathrm{O}$. This result brings up several questions as to the rate of hydrolysis. While this sample is 11 days older than the aged $\gamma-\mathrm{UO}_{3}$ sample, it is more hydrolyzed. More work needs to be done to determine if different polymorphs of $\mathrm{UO}_{3}$ hydrolyze at different rates or if the rate of hydrolysis is not linear. 


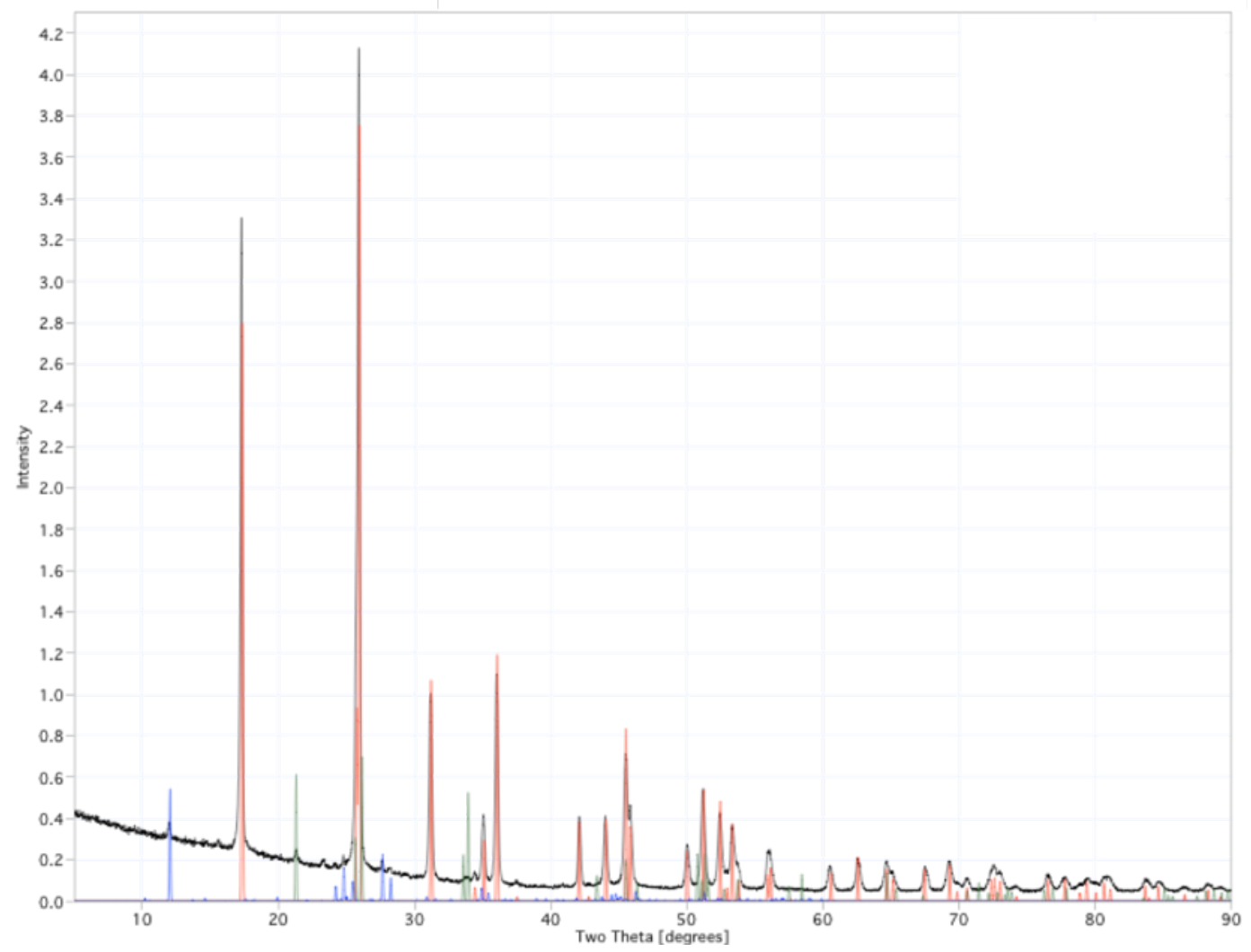

Figure 13: Powder XRD pattern of a sample of $\alpha-\mathrm{UO}_{3}$ that was allowed to sit in a capped vial for 45 days (black). The sample was $90 \% \alpha-\mathrm{UO}_{2}(\mathrm{OH})_{2}$ (red calculated pattern), $5 \% \alpha-\mathrm{UO}_{3}$ (green calculated pattern), and $5 \%\left(\mathrm{UO}_{2}\right)_{4} \mathrm{O}(\mathrm{OH})_{6} \cdot 5 \mathrm{H}_{2} \mathrm{O}$ (blue calculated pattern).

\subsection{Progress on Model Development}

Thermodynamic and structural information have been collected on many of the applicable uraniumoxygen phases from the literature. Formation energies are summarized in Table 2, while Tables 3 and 4 summarize volume changes and lattice parameters of each applicable phase. We have developed a phasefield medol for simulating amorphous $\mathrm{UO}_{3}$ to orthorhombic transition ( $\alpha$ phase) transition. Test and validation still needs to be completed. The coding of the model was started but due to time constraints a functioning model was not completed. 
Table 2: Formation energies $(\Delta \mathrm{G})$, enthalpies $(\Delta \mathrm{H})$, entropies $(\Delta \mathrm{S})$ and heat capacity $\left(\mathrm{C}_{\mathrm{p}}\right)$ of $\mathrm{UO}_{3}$ polymorphs and other phases applicable to the $\mathrm{UO}_{3}$-water system found in the literature. ${ }^{8}$ All data refer to the reference temperature $298.15 \mathrm{~K}$ and to the standard state, i.e., a pressure of $0.1 \mathrm{MPa}$.

$\begin{array}{lllll} & \Delta_{\mathrm{f}} \mathrm{G}_{\mathrm{m}}{ }^{0}(\mathrm{~kJ} / \mathrm{mol}) & \Delta_{\mathrm{f}} \mathrm{H}_{\mathrm{m}}{ }^{0}(\mathrm{~kJ} / \mathrm{mol}) & \mathrm{S}_{\mathrm{m}}{ }^{0}(\mathrm{~J} / \mathrm{mol} / \mathrm{K}) & \mathrm{C}_{\mathrm{p}, \mathrm{m}}{ }^{0}(\mathrm{~J} / \mathrm{mol} / \mathrm{K} \\ \text { Amor. } \mathrm{UO}_{3}: & & & & \\ \alpha \mathrm{UO}_{3}: & -1135.33+1.5 & -1212.41+1.45 & 99.4+1.0 & 81.84+0.3 \\ \beta \mathrm{UO}_{3}: & -1142.30+1.3 & -1220.3+1.3 & 96.32+0.4 & 81.34+0.16 \\ \gamma \cup \mathrm{O}_{3}: & -1145.74+1.2 & -1223.8+1.2 & 96.11+0.4 & 81.67+0.16 \\ \delta \mathrm{UO}_{3}: & & -1213.73+1.44 & & \\ \varepsilon \mathrm{UO}_{3}: & & -1217.2+1.3 & & \\ & & & & \\ \mathrm{UO}_{2}: & -1031.83+1.0 & -1085.0+1.0 & 77.03+0.2 & 63.60+0.08 \\ \alpha \mathrm{UO}_{2.95}: & & -1211.28+1.2 & & \\ \beta \mathrm{U}_{3} \mathrm{O}_{8}: & & & & \\ \mathrm{U}_{12} \mathrm{O}_{35}: & & & & \end{array}$

Table 3: Densities and volumes of uranium oxide phases of interest found in literature. ${ }^{7}$ Exp. $=$ experimentally determined. X-ray $=$ determined by the unit cell obtained from $\mathrm{x}$-ray diffraction experiments.

$\begin{array}{lllc} & \text { Exp. }\left(\mathrm{g} / \mathrm{cm}^{3}\right) & \text { X-ray } & \text { Volume changes } \\ {\text { Amorphous } \mathrm{UO}_{3}:}: & 6.80 & & 0 \\ \alpha \mathrm{UO}_{3}: & 7.30 & 7.44 & -0.0838 \\ \beta \mathrm{UO}_{3}: & 8.25 & 8.30 & -0.2169 \\ \gamma \mathrm{UO}_{3}: & 7.80 & 8.00 & -0.1617 \\ \delta \mathrm{UO}_{3}: & 6.69 & 6.60 & +0.0228 \\ \varepsilon \mathrm{UO}_{3}: & 8.54 & 8.67 & -0.2654 \\ \zeta \mathrm{UO}_{3}: & 8.62 & 8.86 & -0.2853 \\ \mathrm{UO}_{2}: & & & \\ \alpha \mathrm{U}_{3} \mathrm{O}_{8}: & 10.95 & 10.96 & \\ \beta \mathrm{U}_{3} \mathrm{O}_{8}: & & 8.395 & -0.2346 \\ \mathrm{U}_{12} \mathrm{O}_{35}: & & 8.326 & -0.2244 \\ & 7.72 & 8.39 & -0.1846\end{array}$


Table 4: Crystal structure unit cell parameters for different uranium oxides obtained from literature. $^{7}$

\begin{tabular}{|c|c|c|c|c|c|c|c|}
\hline & Structure & $a$ & $b$ & c & $\alpha$ & $\beta$ & $\gamma$ \\
\hline$\alpha \mathrm{UO}_{3}$ : & orthorhombic & 6.84 & 43.45 & 4.157 & & & \\
\hline$\beta \cup \mathrm{U}_{3}:$ & monoclinic & 10.34 & 14.33 & 3.91 & & 99.03 & \\
\hline$\gamma \cup \mathrm{UO}_{3}:$ & orthorhombic & 9.81 & 19.93 & 9.71 & & & \\
\hline$\delta \mathrm{UO}_{3}:$ & cubic & 4.16 & & & & & \\
\hline$\varepsilon \cup_{3}$ & triclinic & 4.002 & 3.841 & 4.165 & 98.1 & 90.2 & 120.17 \\
\hline$\zeta \mathrm{UO}_{3}:$ & orthorhombic & 7.511 & 5.466 & 5.224 & & & \\
\hline $\mathrm{UO}_{2}:$ & cubic (fcc) & 5.47 & & & & & \\
\hline$\alpha U_{3} \mathrm{O}_{8}:$ & orthorhombic & 6.716 & 11.960 & 4.147 & & & \\
\hline$\beta \mathrm{U}_{3} \mathrm{O}_{8}:$ & orthorhombic & 7.069 & 11.445 & 8.303 & & & \\
\hline $\mathrm{U}_{12} \mathrm{O}_{35}:$ & orthorhombic & 6.91 & 3.92 & 4.16 & & & \\
\hline
\end{tabular}

\subsection{Conclusions}

Three routes to the preparation of $\mathrm{UO}_{3}$ were explored. From our studies of the conversion of $\mathrm{UO}_{2}\left(\mathrm{NO}_{3}\right)_{2}$ to $\gamma-\mathrm{UO}_{3}$ we found that this conversion can take place at a lower temperature than previously reported $\left(350^{\circ} \mathrm{C}\right)$. We discovered that $\left(\mathrm{NH}_{4}\right)_{4} \mathrm{UO}_{2}\left(\mathrm{CO}_{3}\right)_{3}$ can be converted to an amorphous phase and $\beta$ $\mathrm{UO}_{3}$ and it can also be converted to a mix of $\alpha$ - and $\beta-\mathrm{UO}_{3}$ depending on the temperature of preparation. We demonstrated that $\mathrm{UO}_{4} \cdot 2 \mathrm{H}_{2} \mathrm{O}$ can be converted to $\alpha-\mathrm{UO}_{3}$.

Preliminary aging studies of $\alpha$ - and $\gamma-\mathrm{UO}_{3}$ were conducted. The hydrolysis products of $\mathrm{UO}_{3}$ were identified $\left(\alpha-\mathrm{UO}_{2}(\mathrm{OH})_{2}\right.$ and $\left.\left(\mathrm{UO}_{2}\right)_{4} \mathrm{O}(\mathrm{OH})_{6} \bullet 5 \mathrm{H}_{2} \mathrm{O}\right)$ and pure forms of these phases were made in order to establish their Raman and fluorescence spectra. The rate of hydrolysis of the $\alpha$ - and $\gamma-\mathrm{UO}_{3}$ samples appeared to be different. More work needs to be done in order to understand why these rates were different. Also, more work needs to be done to use the developed spectroscopic library to quantify the degree of hydrolysis for a $\mathrm{UO}_{3}$ product.

The developed spectroscopic library is beginning to demonstrate its value with the fluorescence study of $\alpha-\mathrm{UO}_{3}$. While this sample appeared to be pure according to the powder XRD pattern, a rapid (1 second acquisition time per spectra) fluorescence spectroscopic analysis allowed us to quickly identify hydrolysis products and starting materials in the sample. We should now be able to apply the same type of analysis using Raman spectroscopy. 


\subsection{References}

1. Wheeler, V. J.; Dell, R. M.; Wait, E., Journal of Inorganic \& Nuclear Chemistry 1964, 26 (11), 18291845.

2. Hoekstra, H. R.; Siegel, S., Journal of Inorganic \& Nuclear Chemistry 1961, 18, 154-165.

3. Greaves, C.; Fender, B. E. F., Acta Crystallographica Section B-Structural Science 1972, 28 (DEC15), 3609-3614.

4. Debets, P. C., Acta Crystallographica 1966, 21, 589-\&.

5. Hoekstra, H. R.; Siegel, S., Journal of Inorganic \& Nuclear Chemistry 1958, 7 (1-2), 174-175.

6. Engmann, R.; Wolff, P. M. D., Acta Crystallographica 1963, 16 (10), 993-\&.

7. Benedict, M.; Pigford, T. H.; Levi, H. W., Nuclear Chemical Engineering (2nd Edition). McGraw-Hill.

8. Gullaumount, R.; Fanghanel, T.; Fuger, J.; Grenthe, I.; Neck, V.; Palmer, D.; M, R., Update on the

Chemical Thermodynamics of Uranium, Neptunium, Plutonium, Americium and Technetium. Elsevier: 2003. 



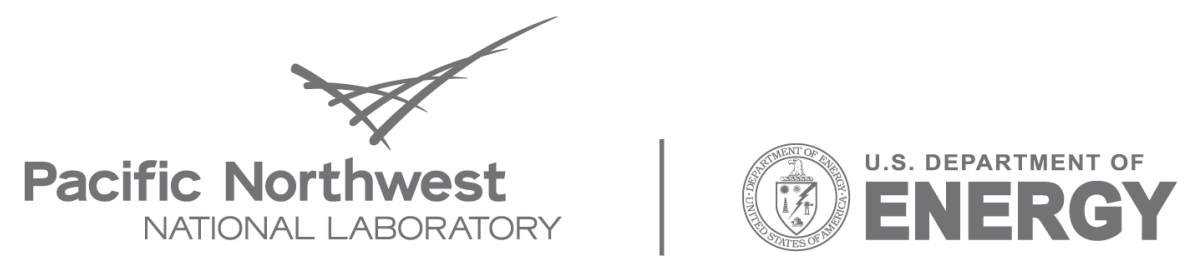

Proudly Operated by Battelle Since 1965

902 Battelle Boulevard

P.O. Box 999

Richland, WA 99352

1-888-375-PNNL (7665)

www.pnl.gov 